\title{
Voices from the chat rooms: research into the experiences of Chinese students participating in transnational education programmes as reported on internet social networks
}

\author{
Dave Burnapp and Wei Zhao, University of Northampton
}

\begin{abstract}
This paper reports on research using postings on websites and online discussion boards to explore the experiences of Chinese students participating in transnational education programmes. It develops the concept of Virtual Third Spaces and establishes themes for future research which will use primary data collection methods. The themes identified relate to: differences in the theories of education; differences in the study methods; issues relating to choice, change, and personal development; quality of the courses and colleges providing the courses; and recognition of qualifications. Issues relating to the use of English as the medium of instruction permeate all these other themes.
\end{abstract}

Keywords: transnational education, social network, Virtual Third Space, internet research, HND.

\section{Background}

This is an initial output from a Higher Education Academy (HEA) funded project which is researching international collaborations in Higher Education. This aims to investigate current types of collaborations and produce case-studies to enable the production of an online tool to help institutions learn from previous experiences in the sector. Recent research has shown that such internationalisation is likely to grow (Böhm et al, 2004) and this growth is typified by increasing complexity and diversity. Middlehurst \& Woodfield (2007) report several dimensions of change: new patterns of recruitment of international students as markets become mature and new markets emerge; increased competition; and new modes of delivery. Examples include: staff exchanges; strategic partnerships with companies and regional development agencies; joint degrees; collaborative research; distance and online learning; and the foundation of overseas campuses. All have different impacts on different stakeholders, as each form of collaboration makes particular demands and promises specific outcomes across the participating institutions. This paper, however, will focus on one particular group of stakeholders (students in China) in one particular form of collaboration (transnational programmes, where students remain in their home countries while participating in courses run by foreign institutions).

\section{Theoretical Framework}

The term 'Third Space' was developed by Bhabha (1990) to describe something more than just an overlapping of resources drawn from two cultures, implying instead a fertile, generative opportunity, involving hybridisation, synergy, and reflection on experience. Applying this to the experiences of international students, Burnapp (2006) 
showed that identity is linked to culture but is not fixed by culture, and that students are influenced by their original cultures of learning but are not constrained by them. Using a classification of types of outsideness and insideness (Relph 1976), Burnapp suggested that initially students entering a new culture of learning may achieve behavioural insideness, i.e. an understanding of the performance requirements, and may later achieve empathetic insideness, i.e. being involved at emotional levels and identifying with the setting. They still stop short, however, of achieving the existential insideness of those for whom this is home. He suggested a positive outcome: they may become equipped with the competences and perspectives of two cultures of learning, so may create a 'Third Space'. Burnapp and Yan (2007) conducted research to examine uses made of unofficial online support systems by Chinese Students in a British University, to further develop the concept of Third Space. They suggested that social networking communities, using Chinese language online peer support as a resource, amount to a Virtual Third Space, as the students reported using the internet to generate a hybridisation of Chinese and English resources and methods of studying.

\section{Research context}

The research reported on here stands on three recent developments: the growth of transnational education; increased interest in research into students' experiences of international education; and the rapid take-off of internet social networking.

\subsection{Transnational education}

The 'Million +' association of universities' report identified 'transnational' education, following courses run by foreign institutions in students' home countries, as an area of rapid growth (Woodfield \& Middlehurst 2009). One example is Higher National Diploma programmes arranged in China by the Scottish Qualifications Authority in a collaboration with the Ministry of Education of China. In this five year programme there is a foundation year taught in China, then two years of an HND course taught in China, the fourth year is a top-up to degree level taught at UK universities, and this allows progression to Masters degrees in the fifth year (SQA n.d.).

\subsection{Research into students' experiences of international education}

Research concerning internationalisation increasingly accesses the experiences of students involved in collaborations (Coates 2006; Hyland et al 2008; Foster 2008; Sovic 2008), however most research already published focuses on international students' experiences when they move across borders and enter new educational systems abroad, rather than those engaged in transnational programmes.

\subsection{Rapid take-off of internet social networking and e-learning}

There is a rapid growth and high rate of use of internet social networking in China: Godula et al (2009) report that there are around 300 million internet users in China, with 200 million under 29. A key feature is the low usage of non-Chinese platforms such as Facebook compared with the dominance of Chinese platforms such as Bulletin Board Systems (BBS) which allows anonymous postings, Qzone which is aimed primarily at teenagers, Kaixin001 which added 30 million mostly white-collar users in one year, and Xiaonei which has around 40 million student users. Liu \& Zoninsein (2007) state that 'a different kind of Internet culture is emerging in China younger, more devoted, more addicted to speed and intimacy than its Western counterparts,' and also that 'Chinese also seem to be more likely than Americans to 
use the Web to share and form opinions'. Within education, Kang \& Song (2007) report rapid growth leading to estimates of 10.54 million e-Learners in China for 2007.

\section{Research Methods}

The researchers conducted an examination of internet sites where Chinese students report their experiences of transnational education with the aim of testing two assumptions which may seem to be implicit in the growth of transnational education and its role in subsequent progression to cross-border education.

The first of these assumptions is that as transnational education removes the difficulties of social adaptation encountered by students who physically move to new sites of education, it may therefore be an easier transition for them to make. Against this, however, it is possible that the academic adaptation required, including what Welikala \& Watkins (2008) describe as cultural scripts of learning, may be more difficult because cultures of education are likely to reflect to some extent the prevalent ideologies which are exhibited daily in such things as how the news is reported (for example whether several views are presented or just one official view), or how decisions are made in workplaces (using either horizontal or vertical decision making structures), or expectations of whose voices have the right to be heard in certain scenarios.

The second assumption concerns the subsequent transition to cross-border top-up courses: there may be an expectation that this physical transition will be nonproblematic as these students have already been participating in UK courses transnationally.

Examining online postings and discussions is a form of non-participant observation in a naturalistic setting yielding secondary qualitative data. Using the internet to research is increasingly accepted, and earlier concerns about the quality of internet samples have been countered by those who claim that such samples are at least as representative as those created in other forms. (For a discussion of this see Hewson et al 2003, pp26-54). Concerning the approach reported here, which explores the select group of those participating in transnational educational programmes, these authors point out that this 'is concerned not with making broad generalisations, but with exploring and elucidating individual perspectives' (Hewson et al 2003, p30).

The decision to find comments written in the students' first language was influenced by a project at the University of the Arts London. In that research, interviews were conducted by post-graduate research assistants who were first-language speakers of the languages used: 'The interviews provided rich insights precisely because the language barrier had been eliminated: students could express their thoughts more easily in their native language, and to their co-nationals' (Sovic 2008, p7). In this case online postings were analysed by a Chinese research assistant, rather than conducting spoken interviews, but this still allowed a greater confidence in the authenticity of the experiences than would have been the case if the research had necessitated gathering Chinese students' perspectives using English language. The initial analysis identified key themes, and subsequently a range of viewpoints connected to each theme were 
gathered. The examples included below were compiled from different sources in order to ensure non-traceability (so specific voices cannot be identified) whilst retaining the richness of experience associated with qualitative research in the participants' own language.

\section{Findings}

The keywords 'SQA HND' were used in the search engine www.baidu.com which yielded sites created by Yinhong International, which is a subsidiary of the Chinese Service Center for Scholarly Exchange (CSCSE), which is itself affiliated to the Chinese Ministry of Education with responsibilities for international scholarly exchanges. According to the website of CSCSE there are twenty three Chinese universities which offer SQA HND programmes. There are five main study topics and fourteen subjects are available. These five study topics are: business and management; IT and computing; tourism and hospitality; engineering; and logistics. Yinhong reports that now there are more than ten thousand candidates studying SQA HND courses. Three years after the programme was launched $92.8 \%$ got the HND diploma, and 2124 students went aboard for higher education. The web pages for each of the colleges affiliated to the SQA HND linked to the Yinhong site use student voices as an endorsement of their courses, and in the extracts reported below these are referred to as 'official' sites. In addition, using an advanced search option (BBS, Bulletin Board System, an internet forum system) the keyword 'HND' produced a list of over 8,000 current discussion threads created by students themselves, and in the extracts reported below these are referred to as 'student generated'. Many of these threads related to personal questions and so are not related to this research, for example students asking about the living condition in a college, or another which concerned a student trying to get a female friend in college. The process of selecting relevant data from a large source is described by Chenail (1995) as winnowing, and hence there is always some degree of reduction, and the examples given below were chosen to illustrate themes which relate to the two assumptions referred to above.

The themes identified in the initial review were:

- Differences in theories of education between courses previously experienced and those informing these students' current HND courses.

- $\quad$ Differences in the study methods previously experienced and those required by the HND courses, including autonomous learning, group work, and application activities.

- $\quad$ Issues relating to choice, change, and personal development.

- Issues relating to the quality of courses and colleges, including care of students, cost, and value for money.

- Issues relating to recognition of qualifications.

The use of English permeates all these, so is not separated as a specific theme. As examples of this, extract 2 below links differences in theories of education to the use of English in teaching, and extract 3 links differences in study methods to opportunities to develop English proficiency. Extract 4 does not specifically mention English, but the complaint about the volume of assessment work surely is compounded by the need to use a foreign language. 


\section{Theme 1: differences in theories of education}

The extracts below have been translated into English, however the original Chinese texts are given in the appendix of this paper because, as pointed out above, the original words used by participants should be used as far as possible to capture their perspective of the situation being described. The first extract, from an official source, reports reasons why a student chose to study this programme:

\section{Extract one (Official)}

“... the reasons for me to choose it [study HND], is in the first place because the educational theory of HND programme focuses on quality; the personalised choice for the future study, and the excellent high standard of facilities and teacher..."

Another student also describes the educational theory of the HND programme. She was in her second year, and she links several of the themes identified above:

\section{Extract two(Official)}

"The educational theory is different. ... In Chinese education system, to get scores decides everything. ... Therefore, most Chinese students were educated to follow what the books said from the beginning. After a long time, these students' creativities were lost. However, I was attracted by the different education theory when I first got to know about British higher education programmes. The quality of our study is improved enormously, because the HND program course was taught in English by the teachers with rich experiences about foreign culture. In addition, the Chinese and foreign educational experts have set up an auditing organisation to make sure the quality of HND programme is taught in the correct academic standard, ..."

\section{Theme 2: differences in study methods}

The student quoted above also describes personal impacts of the adoption of new study methods:

\section{Extract 3 (Official)}

"There is freedom in the study here, the study method is flexible. I went to library after lessons ... I have learnt how to enjoy study. ... I also enjoyed the pleasure of self-learning process. ... In the programme, I noticed that English is playing a very important role during study process. ... Every student tried to use English to communicate with each other. Our English has improved after practice and making mistakes. In the meantime, a number of different student societies were set up by the Students Union. For example, the entrepreneurial 
student society was set up to link the business theories with the business practice."

Postings on the student discussion boards, however, are sometimes rather more critical about the differences in methods of studying:

Extract 4 (Student generated)

"I am also a HND Programme student who was doing international business course. To be honest, the HND programme is disgusting, especially the final year. I was doing my dissertation every day at home. It was usual for me not to go out during one month. ... In addition, the college which manages the HND programme does not take responsibilities to look after their students. This causes students to complain."

It would seem that, as well as being unhappy about the amount of assessment work, this student was unused to the demands of continuous assessment rather than end-ofyear assessments. Another student (extract 5 below) describes adopting new ways of studying and links this to the next theme of change and personal development.

\section{Theme 3: choice, change, and personal development}

This extract is one of several which has a flavour of true reflection:

\section{Extract 5 (Official)}

"I could not get used to the new way of studying when I first started the HND course. In the Chinese high school, I have not developed the self-study habit. My study method was to listen to what the teacher said and to make notes. I adopted self-learning method after half year of the HND programme. ... In the class, the teachers use discussions, presentations and role play teaching methods to demonstrate the theories, and then group work to connect the theories and real situations together. This kind of study method and environment makes me become more outgoing and confident."

A student from a university in Shanghai is very open about her feelings of personal change:

\section{Extract 6 (Official)}

"During one year studying and living under this college's supervision, I feel positive about my future. I grow up little-by-little, and I also notice that I alone should take responsibility for any decision about my future and life. In the class I become more confident ... I can see my bright future."

\section{Theme 4: quality, cost and value for money}

Before addressing the quality of the programmes it is necessary to understand these courses (even before considering the cost of any progression courses involving overseas study) are expensive, so naturally some students examine carefully whether the benefits match the costs. One student suggests:

Extract 7 (student generated)

"Everyone needs to be careful about this. If you make a wrong decision about choosing to study HND, you will lose around 20,000 to 30,000 RMB (around $£ 2,000-£ 3,000)$. Therefore, you might lose around 100,000 RMB (£10,000) in total when you finish HND in total four years. However, if you make a wrong decision about studying abroad after finishing HND in China, you might regret 
this ... because the study fee to study abroad is around 200,000 RMB (£20,000) per year."

Concerning quality, some students believe that their programme has problems concerning course management. For example, one student described his experience about the course he was offered and the course he eventually studied:

Extract 8 (student generated)

"I am a student who is doing HND programme in X university. When I was accepted, the offers from the university indicated that I had been accepted in the international business course. However, the students who were going to study international business course were then told that this subject is no longer available for study because the number of students choosing this subject is too small, therefore it is not worth to open this course. In the end, I have found out that the course which is written on the offer is just for show."

Other students from the same college added comments after reading this posting:

Extract 9 (student generated)

"I had the same experience. I was going to do hotel management. But, the college told us this course is cancelled because there were only two students who had registered, so it is not worth opening this course. In the end after the new term started, I found that one third of the students would have liked to study hotel management. The college told them the same reason and made them change their course to international business."

A third student joined in this particular discussion:

Extract 10 (student generated)

"That is right. The college told us there are two courses which are available for students in the recruitment stage, we all wanted to study hotel management course. In the end, only one course was available, because the college wanted to reduce the investment on the course therefore they do not need to hire a teacher to teach this course."

In contrast, some students believe that it is unfair to only blame the HND programme and the institutions for causing dissatisfaction. They suggest some students also should think about their own weaknesses:

Extract 11(student generated)

"Some HND students complained that they have not learned anything during the HND programme. I believe this problem is actually caused by these students themselves. I would like to know how many students have passed the exams and did not need to do a resit. How many students have got IELTS 6.0 on their IELTS test in HND programme in year two?"

\section{Theme 5: recognition of qualifications}

The next extract refers to the social recognition of HNDs. In Chinese universities people studying diploma courses do not have the same respect as people on degree courses. This student mentioned that:

Extract 12 (student generated)

"More of the students said that they were disappointed about the HND programme, and they said they were studying a rubbish programme. However, 
even if you are going to study a BA degree in Chinese universities, well so what? I have seen many BA students who are not better than us. At least, our English is better than theirs. ... We were studying in the new system of education. ... the concept is different from the traditional Chinese education system. The format and requirements of our dissertation is more closely connected with the work practice and requirements. I really felt that because I am working now."

Formal recognition of qualifications is also an issue. A Chinese HND student successfully completed the HND programme study and finished the final year of BA degree in a UK university. However, this student reports problems in getting the Chinese Ministry of Education to recognise his degree and education:

Extract 13 (student generated)

"We have been studying with local British students in the final year of BA degree. We also have done the same University activities like doing graduation project. We have spent more time and energy in order to get the same qualification. We finally got it. However, because we have done the HND programme in China, therefore our qualification cannot be recognised. I would like to know why the Chinese Ministry of Education introduced this programme (HND programme)? Even the students who studied HND programme outside China and have finally had BA degree, their qualification can be recognised. I think that the Chinese Ministry of Education, the members of Foreign Academic Degrees Verification of Overseas Educational Information, and all the teachers and colleges which promote the HND programme should consider how to develop and improve the HND programme and how to make it better. Please do not just think how to make profit out of this programme and how to cheat on people."

\section{Discussion}

Those websites created by Yinhong International to promote HND programmes mostly report positive comments of students about their HND programmes, and can be considered recruitment websites intended to attract new students. There are, however, no responses from other students to these reflections, that is to say they are really 'old web' where information is statically posted rather than 'new web' or web 2.0, which permits interaction. For this research the value of these sites was that they set an agenda of relevant issues (and in fairness also present some examples of thoughtful reflection). However the postings on the student generated discussion boards offer the opportunity to observe real interactions, exchanges of views, and social construction of meaning as the students create their understanding of the novelty of this situation, in short the creation of a Virtual Third Space.

Concerning the first of the two assumptions this research set out to investigate, that transnational education removes the difficulties of social adaptation encountered by students who physically move to new sites of education: it would seem that the focus of these students' discussion did concern academic integration and that this differs from earlier research concerning students who physically cross borders which found that social and academic factors were mixed and compounded each other (Burnapp 2006). In addition (for example extracts 2, 3, and 5) do seem to chart a trajectory of 
adjustment moving from behavioural insideness (getting to understand the requirements) to empathetic insideness (getting to identify with these requirements) however this adjustment was not universal (extract 4). The second assumption concerning the subsequent transition to cross-border top-up courses will be investigated in the next stage of this research which will be described below.

\section{Conclusion}

The research reported here therefore has achieved two things. Firstly it suggests further evidence of a Virtual Third Space created by students engaged in the crossing of educational systems (and the implicated cultural systems) using the internet to share and develop opinions and feelings, which this research project will continue to explore. Secondly the themes identified in this initial exploratory stage will be taken forward to frame later stages of research. In this subsequent research the second of the two assumptions mentioned earlier, concerning preparedness for physical movement for top-up courses, will be tested by comparing attitudes and expectations of students who transfer to courses in the UK from transnational courses in China with those who transfer from courses within the Chinese culture of education. By examining the expectations and experiences of two sub-groups of students within one cohort (those from transnational courses in China with those from diploma courses of the same level but taught in the Chinese system) quasi-experimental methods will be employed, using primary data collection methods, some qualitative and some quantitative, some online and some face-to-face, in order to create a longitudinal analysis of the experiences of students on these two types of programmes.

\section{References}

Böhm, A., Follari, M., Hewett, A., Jones, S., Kemp, N., Meares, D., Pearce, D., Van Cauter, K. (2004) Vision 2020. Forecasting International Student Mobility: a UK Perspective. British Council.

Burnapp, D. (2006) Trajectories of adjustment of international students: U-curve, learning curve or third space. Intercultural Education, 17, (1), 82-93.

Burnapp, D. \& Yan, F. (2007) Exploring Digital Third Spaces - an inquiry into the use of digital support systems by Chinese Students in a British University. Proceedings of the 5th International Conference on ELT in China and the 1st Congress of Chinese Applied Linguistics Beijing May 16-21 2007.

Chenail, R. J., (1995) Presenting Qualitative Data. The Qualitative report. [online] vol 2 (3) Available from http://www.nova.edu/ssss/QR/QR2-3/presenting.html [Accessed 30th October 2009]

Coates, N (2006) Learning, working and 'Touching the Culture': the social situation of Chinese students at the University of Salford. SEEK: Salford Environment for Expertise and Knowledge. 
Foster, M. (Ed) (2008) Enhancing the Experience of Chinese Students in UK Higher Education - Lessons from a Collaborative Project. London: SEDA.

Godula, G., Li, D., \& Yu, R. (2009) Chinese Social Networks 'Virtually' Out-Earn Facebook And MySpace: A Market Analysis. Techcrunch. Available at: http://www.techcrunch.com/2009/04/05/chinese-social-networks-virtually-out-earnfacebook-and-myspace-a-market-analysis/ Accessed 17.06.2009.

Hewson, C., Yule, P., Laurent, D, and Vogel, C. (2003) Internet Reserch Methods. London: Sage.

Hyland F., Trahar S., Anderson J., Dickens, A. (2008) A Changing World: the internationalisation experiences of staff and students (home and international) in UK Higher Education. Escalate. Available at http://escalate.ac.uk/4967 [Accessed 16.06.2009]

Kang, F. \& Song G. (2007) e-Learning in Higher Education in China. In H.SpencerOatey (Ed), e-Learning Initiatives in China. Hong Kong: Hong Kong University Press.

Liu, M., \& Zoninsein, M. (2007) These Surfers Do It Their Own Way. Newsweek. Available at: http://www.newsweek.com/id/78112 [Accessed 26.06.2009]

Middlehurst, R., and Woodfield, S. (2007) Responding to the internationalisation agenda: implications for institutional strategy. The Higher Education Academy.

Relph, E., (1976) Place and Placelessness. London: Pion.

Sovic, S (2008). Lost in Transition: The International Student's Experience Project. London: University of the Arts.

SQA (n.d.) The Five Year Plan. Scottish Qualifications Authority. Available at: http://www.sqa.org.uk/sqa/7921.738.html [Accessed 16.06.2009].

Welikala, T., and Watkins, C., (2008) Improving Intercultural Learning Experiences in Higher Education. London: Institute of Education

Woodfield, S. \& Middlehurst, R. (2009) Universities and International Higher Education Partnerships: making a difference. Million+

\section{About the authors}

Dr Dave Burnapp is Senior Lecturer in Languages and MFL in Northampton Business School at the University of Northampton, and is a National Teaching Fellow.

Wei Zhao is Research Assistant, HEA Internationalisation Project, at the University of Northampton. 


\section{Appendix 1 \\ Original Texts}

\section{Theme 1: differences in theories of education}

Extract one (Official)

“...之所以选择它, 绝不是一时的冲动，绝不是一时的茫然。而是看中了它质量 第一的教学理念, 个性化的学业生涯设计, 还有雄厚的师资力量...”

Extract two (Official)

"这里的教学理念与众不同。…中国的教育制度就是分数决定一切，...

莘莘学子的创造力就在那一次次对权威妥协和退让的过程中磨灭。然而，当我 第一次接触到英国高等教育文凭项目的教学方式时，我就被它的独树一帜给吸 引了。全英文的授课方式, 与英国同步的教材, 有丰富海外留学经历的资深老 师以及由中外专家共同组成学术质量监督委员会都让我们的学习质量大大地提 高, ..."

\section{Theme 2: differences in study methods}

Extract 3 (Official)

“这里的学习是自由的, 这里的学习方式是开放的。课后的我, 流连忘返于图书 馆。… 学会了如何去享受学习; ...

体会到了自主学习的乐趣。课后的我，表情于英语角的交流中。… 在英国高等教育文凭项目的学习中，我清楚地知道，英语对我的学习起着举足 轻重的作用，...

每一个人都在用不很流畅的英文沟通着, 在那一次次的尝试和失败中, 英语自 然而然地进步了。与此同时, 英国高等教育文凭项目学生会还成立了社团。我 们是学商科的，因此，社会实践和如何把课本知识现实化相当重要，在这样的 特殊要求下，创业协会应运而生"

Extract 4 (Student generated) 
“我也是HND国际商务专业的学生。说句实话HND专业课程确实很恶心，尤其 是最后一年。整天就是在家闷着头写论文, 一个月见不到太阳都是很常见的。 ... 再加上有的学校不负责, 管生不管养。弄得学生确实意见很大."

\section{Theme 3: choice, change, and personal development}

Extract 5 (Official)

"刚进校的时候，一种全新的学习方式

让我有点无所适从。在上中学的时候, 我一直处在一种被动的学习状态中，老 师讲什么, 了主动学习的习惯。 $\cdots$

在课堂中，老师们会用讨论，演讲和角色扮演的我就听什么，做好的笔记就是 老师所要讲的重点了。经过半年的大学学习后, 我养成方式来强化我们的理论 知识, 然后通过小组案例分析的方式, 把理论应用于实践。在这种轻松的学习 环境中，我变得更加自信、开朗。

Extract 6 (Official)

一年来, 在某某大学良好的生活与学习环境、以及严谨的管理培育下，使我感 到了命运对我的青睐：我从一个对人生未来慒懂的小女孩, 渐渐长大, 渐渐知 道了要对自己的人生与未来负责, 担起属于自己的生命之“重"; 小班化的教学 ，给了我勇气，... 使我对未来充满希望。

\section{Theme 4: quality, cost and value for money}

Extract 7 (student generated)

"大家一定要慎重，如果说你选择HND选错了那可能损失的是 $2 \sim 3$ 万, 顶到头 4 年都读完了最多也不过 10 万。但是哥们您要是出国以后后悔了那你可真亏了。

。。-年下来20万不多吧"

Extract 8 (student generated)

“我是今年升专业课第一年的某某大学hnd学生 在去年 当我被这所学校录取的 时候 通知书上明明白白写着我录取的专业是国际商务 但是到了今年 无耻的某 某大学HND竟然对我们这些读这个专业的学生说这个专业不开了 理由是读这 
个专业的人太少了后来据我了解 原来 录取通知书上被录取的专业完全做给人 看的 根本就没有."

Extract 9 (student generated)

“我们当初也是, 我是报酒店管理的, 可是学校说, 酒店管理只有两个人报, 才 不开课, 后来开学后, 一问同学, 起码有三分之一的同学都想报酒店管理，都 是被同样的理由转到国际贸易了."

Extract 10 (student generated)

“是啊，当初招我们的时候说有两个专业，我们都想读酒店管理这个专业的，后 来学校为了节约成本确实无耻的改成一个专业了, 老师可以少请了。”

Extract 11 (student generated)

"至于很多学生抱怨HND学不到东西, 我就觉得这根本是他们自己的问题,第一年 预科先别去说它，专业课有多少人通过，有多少人要补考，YEAR 2 的时候有多少 人达到IELTS6.0分，总之一句话，人烂，在哪都是烂，就是要好好刺激刺激那帮整 天不学无术却抱怨不停的人，不喜欢读HND去读大专职校夜校好了，去高复好了， 就算把这帮人送到CAMBRIDGE了又怎么样，别以为在大学里都能学到东西，好 学生永远是自觉学习的,老师只是起到了导向的作用.

再说一遍 烂学生到哪都是烂 要是有人心肝情愿做烂学生 我也没什么好说的."

\section{Theme 5: recognition of qualifications}

Extract 12 (student generated)

“现在很多学生都在说自己学了 HND是上当受骗, 学了一个垃圾项目。其实就 算你上了大学又怎么样? 我见过很多大专科生, 本科生还不如我们。我们英语 比他们强，最起码咱们敢说。 $\ldots$ 咱们接受的是新式教育， ...

他们的教育方式是和传统方式绝对不一样的。我们的论文形式是最接近于工作 需要的。我肯定, 因为我现在工作了我深有感触。”

Extract 13 (student generated) 
"我们是跟普通的英国本地大 3 的学生一起上课, 修学分, 毕业设计, 答辩, 我们获 得了一模一样的文凭,同时我们是付出了更多的心血和压力.但是就是因为我们 的HND是在国内读的，所以不给我们认证学历，那为什么教育部要引进这个项目， 就算在国外读完HND又拿到本科的, 也能正常的认证下去. 所以请教育部,留学 服务中心的老师领导们，还有极力推广HND的这么多学校的老师们，先能真正的 把这个项目改善和完善下去,不要就是想着怎么赚钱怎么骗人的!!!" 